Олексій Полтораков

кандидат політичних наук Військовий інститут Київського національного університету

ім. Тараса Шевченка

ID ORCID 0000-0003-2418-0969

Ірина Щиголь

факультет соціології Київського національного університету

ім. Тараса Шевченка

ID ORCID 0000-0001-5503-2235

DOI: $10.33099 / 2617-1775 / 2021-01 / 246-253$

\title{
СОЦІАЛЬНО-ІНСТИТУЦІЙНІ ПРОБЛЕМИ ПІДГОТОВКИ ОФІЦЕРІВ ЗАПАСУ В СУЧАСНІЙ УКРАЇНІ
}

Система підготовки молодших офіиерів (запасу) в Украӥні, недостатньо відповідає векторам розвитку національного сектора безпеки і оборони (а перш за все його кадрового сегменту). Вона вимагає приниипово серйозного реформування, в т.ч. із урахуванням чинників соціально-економічного та морально-психологічного характеру. Пропонується оптимізувати розподіл підготовки за військово-облійськової спеціальності з урахуванням специфіки регіональних вищих навчальних закладів (технічних, економічних $i$ m.n.). Акцентуалізується проблема розробки, забезпечення та впровадження напрямків та програм підготовки офічерів резерву для новостворюваної системи ТрО.

Ключові слова: вищий навчальний заклад, військова кафедра, офіџер запасу, регіон, військово-облійськова спеціальність, ейджсизм.

Кадровий офіџер - людина, яку ми годуємо в мирний час, щоб у воєнний час вона послала нас на фронт.

Габріель Лауб (1928-1998)

Постановка проблеми. Соціологічні аналізи результатів опитувань громадської думки останніх років переконливо фіксують достатньо високий рівень патріотичних настроїв в Україні та відповідного «ціннісного»/«діяльнісного» розуміння патріотизму.

Так, за останніми даними СГ «Рейтинг» (жовтень 2020 р.) [4], 85\% опитаних позиціонували себе патріотами своєї країни. При цьому наразі патріотично настроєних громадян відносно більше серед старших вікових груп респондентів.

В свою чергу, за актуальними даними Фонду «Демократичні ініціативи» та Центру Разумкова (грудень 2019 р.) [10] основними складовими патріотизму українці вважають передовсім любов до своєї країни (80\%) та готовність захищати свою країну, якщо треба - зі зброєю (64\%).

Ці та інші дослідження доволі чітко фіксують наявність у сьогоднішній Україні відповідного «суспільного запиту», принаймні опосередкованого, на розвиток інституційних спроможностей «конвертації» патріотичних настроїв українців у практичну активність/діяльність. I одним із принципово значущих інститутів в цьому контексті виступає інститут воєнної/військової 
освіти/підготовки, - зокрема, той його (напів)периферійний сегмент, що пов'язаний з підготовкою офіцерів запасу.

Аналіз останніх досліджень і публікацій. Питання підготовки офіцерів запасу [Див. 7] зазвичай знаходяться на (напів)периферії дослідницької уваги військово-освітянського пошуку та науково-аналітичного осмислення. Вони розглядаються передусім в загальному контексті військової освіти [2; 3; 9] та базової підготовки молодшого офіцерського складу ЗСУ й інших т.зв. «силових структур» [1] національного «сектору безпеки».

Мета статті. Метою статті $\epsilon$ артикуляція принципових соціальноінституційних проблем підготовки офіцерів запасу в Україні та визначення ключових напрямів іiі оптимізації в загальному контексті трансформаційного розвитку системи військової освіти в Україні.

Методи дослідження. В процесі написання статті були використані як загальнонаукові методи, так і спеціалізовані. До загальнонаукових методів можна віднести методи дедукції, аналітично-порівняльний метод. До спеціалізованих - аналіз документів, контент-аналіз.

Виклад основного матеріалу. Функціонуюча система воєнної/військової підготовки офіцерів запасу, що дісталася Україні «у спадок» від СРСР, була орієнтованою на масову армію та через це характеризувалася досить спрощеним і недостатньо раціональним підходом до використання кадрового ресурсу взагалі і його освітньо-інтелектуального потенціалу зокрема. Однак така система все менше і менше відповідає сучасним реаліям України [3] - як в сенсі внутрішнього демократичного розвитку соціальної держави, так і в сенсі зовнішніх викликів «гібридної війни» та інституційних тенденцій професіоналізації «сектору безпеки» України.

На сьогодні в Україні система підготовки офіцерів запасу залишається досить масштабною. Перш за все слід вказати на діяльність 10 «класичних» військових вищих навчальних закладів (BВН3), які проводять в т.ч. навчання за програмами підготовки офіцерів запасу. Крім того, більше 50 «цивільних» ВНЗ - практично по всій Україні - мають у своїй структурі відповідні кафедри військової підготовки. При цьому більше 20 з цих військових кафедр ВНЗ були відновлені або відкриті в останні 5-6 років (зокрема, в Луцьку та, хоча й ненадовго, у Херсоні) після початку російської агресії проти України. За офіційними даними Міністерства оборони на середину 2020 р. чисельність курсантів з числа цивільної молоді становила 6273 осіб.

Однак на тлі дійсно чималої кількості ВВНЗ і військових кафедр ВНЗ, що надають можливості тисячам мотивованим громадянам України пройти навчання за програмами підготовки офіцерів запасу i отримати первинне військове звання «молодшого лейтенанта» [5; 6; 7; 14], існує ціла низка значущих проблем $[8,13]$, що не дозволяють системі військової підготовки функціонувати 3 належною часткою ефективності охоплення потенційного контингенту молодшого офіцерського корпусу.

По-перше, значущим $\epsilon$ територіальний дисбаланс розташування військових кафедр ВНЗ, на яких проводяться курси підготовки офіцерів запасу. 
У Києві можна нарахувати 10 ВВНЗ та ВНЗ, які надають таку послугу (НУОУ, ВI КНУ, ВІТІ, УВМА, КПІ, НУБіП, НАУ, КНЕУ, а також НАВС та НАСБУ) і ще кілька - під Києвом (зокрема, в м. Ірпінь ); 7 - в Харкові (ХНУПС, ВІТВ НТУ «ХПІ», НЮА, ХНМУ, а також ХНУВС, НАНГ та НУЦЗ). Тоді як в абсолютній більшості регіонів, за дуже рідкісним винятком (Харків, Львів, Одеса), спектр можливостей проходження програм підготовки офіцерів запасу вкрай обмежений - відносно невеликими кафедрами військової підготовки регіональних ВНЗ і, відповідно, невеликими ліцензованими обсягами наборів на програми.

По-друге, вкрай невеликий спектр можливостей вибору військовооблікових спеціальностей (ВОС), за якими проводиться підготовка офіцерів запасу кафедрами військової підготовки ВНЗ в регіонах. Так, на більшості військових кафедр регіональних ВНЗ (наприклад, в таких обласних центрах як Полтава, Черкаси, Чернігів) спектр ВОС дуже обмежений - переважно кількома загальновійськовими, «піхотними» і «психологічними» спеціальностями. Подібні обмеження практично не враховують ні специфіки самих ВНЗ (технічних, економічних і т.п.), ні спеціалізацій та інтересів самих студентів/курсантів.

Достатньо показовими вбачаються насамперед сьогоднішні напрямки підготовки офіцерів запасу на військових кафедрах Державної академії пенітенціарної служби (м. Чернігів), Університету державної фіскальної служби (м. Ірпінь), Національної академії Державної прикордонної служби (м. Хмельницький) - за ВОС «Бойове застосування механізованих з'єднань, військових частин і підрозділів», а також Університету податкової справи і фінансів (м Дніпро) - за ВОС «Бойове застосування змішаних з'єднань, військових частин та підрозділів зв'язку», «Організація фельд'єгерськогопоштового зв'язку» і т.п.

Для порівняння, в Києві підготовку офіцерів запасу за ВОС «Організація морально-психологічного забезпечення» здійснюється в кожному (!) 3 трьох ВВНЗів (НУОУ, ВІКНУ і ВІТІ).

Похідною проблемою $є$ подальша необхідність оперативного «перенавчання» молодого/молодшого офіцера-«контрактника» [Див. 5], який має готовність проходити військову службу з урахуванням перш за все своїх обставин (його профільної/професійної освіти, загальних інтересів і конкретних побажань) [Пор. 7], 3 одної ВОС на іншу - умовно, 3 «артилериста» на «фінансиста», або навпаки.

По-третє, значущою проблемою соціально-економічного характеру $є$ та обставина, що підготовка на практично всіх військових кафедрах (за дуже рідкісним винятком) проводиться за рахунок юридичних або фізичних осіб [Див. 6]. Однак далеко не всі бажаючі, які будуть гідними, мотивованими та перспективними молодшими офіцерами, можуть фінансово дозволити оплату такого навчання. В силу цього відносно висока вартість навчання на військових кафедрах додатково посилює i без того істотне соціально-економічне розшарування українського суспільства. 
Суміжною проблемою є також те, що заняття на кафедрах військової підготовки ВВНЗ/ВН3 у більшості випадків проходять за т.зв. «методом "воєнного дня"» [Див. 7], тобто раз на тиждень, в основному - але не завжди по суботах (наприклад, в Ужгороді - по п'ятницях).

Інші методи - на кшталт пілотного проєкту 12-місячних «курсів лідерства офіцерського складу тактичного рівня» (на базі ВВНЗів) і т.п. - поки що представляють радше «виключення, що підтверджують загальне правило».

Попри зовнішню привабливість формату т.зв. «воєнного дня» профільний локальний контингент (перш за все так звана «сільська інтелігенція», що має базову вищу освіту) не завжди готовий дозволити собі практично кожен вихідний (а тим більше робочий) день їздити на подібні заходи, а особливо 3 урахуванням загальної проблемності локального транспортного сполучення в «глибинці».

По-четверте, неврегульованими є адміністративно-процедурні складнощі, перш за все щодо проходження військово-лікарської комісії (ВЛК) [11]. Щоб вступити на військову кафедру необхідно пройти ВЛК при військовому комісаріаті - за місцем реєстрації (успадкованого від СРСР інституту обліку як режиму контролю, т.зв. «прописки») та прив'язаному до нього перебуванні на військовому обліку, - в т.ч. 3 огляду на специфіку їхніх режимів роботи, а також обов'язкових вимог здачі медичних аналізів і отримання лікарських довідок, медичних сертифікатів і т.п.

Це $\epsilon$ значущою проблемою, тому що в Україні - в контексті внутрішніх міграцій (в масштабах мільйонів громадян!) - посилюється розрив між місцем формальної «прописки» і фактичного проживання, роботи та/або навчання. (Ця проблематика, до того ж, стосується всіх перспективних військових«контрактників», які живуть, навчаються та/або працюють не за місцем своєї «прописки».)

По-п'яте, не до кінця врегульованою залишається частина загальносуспільної проблеми: «ейджизму» [Див. 15], котра пов'язана з віковими обмеженнями для проходження підготовки за програмою молодших офіцерів запасу і отримання первинного офіцерського звання вже відносно немолодими людьми. У більшості ВНЗ на кафедрах військової підготовки вчать майбутніх офіцерів запасу насамперед з числа своїх студентів, причому з обмеженнями за віком (до 40 або, в окремих випадках, наприклад, в київському НТУ, навіть до 35 років) - найчастіше, на офіційних сайтах ВВНЗів та військових кафедрах ВНЗ це відразу і вказується.

В силу цього «граничний вік до 40 років» для початку навчання на кафедрі військової підготовки виступає т.зв. «скляною стелею», непрямою обставиною дискримінаційного характеру, тобто непрямим порушенням конституційних прав громадянина України [15].

Окреме місце займає проблема підготовки офіцерських кадрів, особливо молодшого офіцерського складу, для створюваної зараз в Україні системи Територіальної оборони (ТрО) [12]. Перш за все з урахуванням того, що (1) специфіка завдань та діяльності ТрО (охорона значущих об'єктів, боротьба 3 НВФ та ДРГ і т.п.) знаходиться на стику функціональних полів Збройних Сил 
(від ССО до ВСП) та Національної гвардії, і (2) структура ТрО не передбачає, зокрема, повноцінних танкових та артилерійських підрозділів. А тим більше, що основний кадровий «кістяк» регіональних підрозділів системи ТрО (область - бригада, район - батальйон) - як раз відносно немолоді (40-55 років), але дійсно мотивовані до служби у військовому резерві патріоти 3 активною громадянською позицією і чималим життєвим досвідом [Див. 12; 15]. 3 одного боку, більшість із сьогоднішніх «резервістів ТрО» не проходило військової служби сучасного зразку (строкової служби або служби за контрактом), але 3 іншого - чимало 3 них має чималий досвід в т.ч. керівної, організаційної і т.п. діяльності. I остання обставина робить їх перспективними керівникамикомандирами, які користуються належними повагою і авторитетом.

Висновки та перспективи подальших досліджень. Все вищевикладене підводить до попереднього висновку про те, що система підготовки молодших офіцерів (запасу), яка функціонує наразі в Україні, недостатньо відповідає ані «внутрішнім» характеристикам i запитам українського суспільства, ані «зовнішнім» реаліям «гібридної війни», що ведеться проти України Росією, - i похідним векторам розвитку національного сектора безпеки і оборони (а перш за все його кадрового сегменту). В силу цього вона вимагає принципово серйозного реформування, в т.ч. 3 урахуванням чинників соціальноекономічного та морально-психологічного плану. Зокрема, варто оптимізувати розподіл підготовки за ВОС з урахуванням специфіки регіональних ВН3 (технічних, економічних і т.п.), а також принципової спеціалізації ВНЗ системи MBC (НАВС та ін.) - на підготовку за ВОС, орієнтованими передовсім на правоохоронну специфіку (НГУ та ін.). Крім того, принципово доцільною вбачається оптимізація процедури проходження ВЛК (не тільки за місцем формальної реєстрації, але також за місцем навчання, роботи або служби). Перспективною вбачається впровадження системи преференцій та пільг передусім щодо оплати навчання на кафедрах військової підготовки для тих громадян, які проходять службу в резерві (передусім в системі ТрО). Окреме місце займає також проблематика науково-методичної розробки, науковоаналітичного забезпечення та науково-прикладного впровадження відповідних напрямків та програм підготовки офіцерів резерву саме для новостворюваної системи ТрО як такої.

\section{ЛІТЕРАТУРА}

1. Балендр А. Перспективні напрями підготовки персоналу Державної прикордонної служби України на основі європейського досвіду. // Науковий вісник Льотної академії. Серія : Педагогічні науки. Кропивницький : ЛА НАУ, 2019. Вип. 5. С. 270-275.

2. Брижатий $\epsilon$. Військова освіта в контексті національної безпеки та оборони сучасний підхід // Військова освіта. Зб. наук. пр. Національного університету оборони України ім. Івана Черняховського. 2020. №1(41). С.35-45.

3. Вітер Д., Мітягін О. Стратегічні пріоритети підвищення боєздатності Збройних Сил України в контексті професіоналізації військової освіти: політики і процедури // Зб. наук. пр. Центру воєнно-стратегічних досліджень. 2020, № 1(68), С. 133-137.

4. «До Дня захисника України» / Соціологічна група «Рейтинг (жовтень 2020 р.) [Електронний

http://ratinggroup.ua/files/ratinggroup/reg_files/rg_defenders_day_102020_press.pdf 
5. Закон Украӥни «Про військовий обов'язок і військову службу» // Відомості Верховної Ради України (ВВР), 1992, № 27, ст.385.

6. І Інструкиія про організацію військової підготовки громадян України за програмою підготовки офіцерів запасу (Затверджено Наказом Міністерства оборони України та Міністерства освіти і науки України, 14.12.2015 р. № 719/1289).

7. Конщепція військової кадрової політики у Збройних Силах України на період до 2020 року (Затверджено Наказом Міністерства оборони України, 26.06.2017 р. № 342).

8. Мариенківський В., Камалов $C$., Клонцак М. Оцінювання ефективності функціонування військових навчальних підрозділів у системі підготовки офіцерів запасу // Військова освіта. 3б. наук. пр. Національного університету оборони України ім. Івана Черняховського. 2020. №2(42). С.174-185.

9. Нещадим M.I. Військова освіта в Україні: історія, теорія, методологія, практика: [монографія]. К. : ВПЦ «Київськ. ун-т», 2003. 852 с.

10. «Патріотизм, мова та зовнішньополітичні пріоритети» / Фонд «Демократичні ініціативи» ім. І. Кучеріва; Центр Разумкова (грудень 2019 р.) [Електронний ресурс] https://dif.org.ua/article/\%20patriotyzm_mova\%20\%20

11. Положення про військово-лікарську експертизу в Збройних Силах України (Затверджено Наказом Міністра оборони України, 14.08.2008 № 402).

12. Полтораков Олексій. Захистимо свій дім - захистимо Україну // Український журнал. 2019. №12. C.21-23.

13. Полтораков Олексій. Чому старі освітня й кадрова системи блокують соціальну готовність і мотивацію громадян до служби у війську // Армія Інформ, 16.11.2020. [Електронний ресурс] https://armyinform.com.ua/2020/11/chomu-stari-osvitnya-j-kadrovasystemy-blokuyut-soczialnu-gotovnist-i-motyvacziyu-gromadyan-do-sluzhby-u-vijsku/

14. Порядок проведення військової підготовки громадян України за програмою підготовки офіцерів запасу (Затверджено Постановою Кабінету Міністрів України, 01.02.2012 p. № 48)

15. Щиголь Ірина. Таких не беруть... в офіцери запасу: «друга молодість» чи «другий сорт»? // Армія Інформ, 16.11.2020. [Електронний ресурс] https://armyinform.com.ua/2020/11/takyh-ne-berut-v-oficzery-zapasu-druga-molodist-chydrugyj-sort/

\section{REFERENCES}

1. Balendr A. Perspektyvni napriamy pidhotovky personalu Derzhavnoi prykordonnoi sluzhby Ukrainy na osnovi yevropeiskoho dosvidu. // Naukovyi visnyk Lotnoi akademii. Seriia : Pedahohichni nauky. Kropyvnytskyi : LA NAU, 2019. Vyp. 5. S. 270-275.

2. Bryzhatyi Ye. Viiskova osvita v konteksti natsionalnoi bezpeky ta oborony suchasnyi pidkhid // Viiskova osvita. Zb. nauk. pr. Natsionalnoho universytetu oborony Ukrainy im. Ivana Cherniakhovskoho. 2020. №1(41). S.35-45.

3. Viter D., Mitiahin O. Stratehichni priorytety pidvyshchennia boiezdatnosti Zbroinykh Syl Ukrainy v konteksti profesionalizatsii viiskovoi osvity: polityky i protsedury // Zb. nauk. pr. Tsentru voienno-stratehichnykh doslidzhen. 2020, № 1(68), S. 133-137.

4. «Do Dnia zakhysnyka Ukrainy» / Sotsiolohichna hrupa «Reitynh (zhovten 2020 r.) [Elektronnyi

resurs]

http://ratinggroup.ua/files/ratinggroup/reg_files/rg_defenders_day_102020_press.pdf

5. Zakon Ukrainy «Pro viiskovyi oboviazok i viiskovu sluzhbu» // Vidomosti Verkhovnoi Rady Ukrainy (VVR), 1992, № 27, st.385.

6. Instruktsiia pro orhanizatsiiu viiskovoi pidhotovky hromadian Ukrainy za prohramoiu pidhotovky ofitseriv zapasu (Zatverdzheno Nakazom Ministerstva oborony Ukrainy ta Ministerstva osvity i nauky Ukrainy, 14.12.2015 r. № 719/1289).

7. Kontseptsiia viiskovoi kadrovoi polityky u Zbroinykh Sylakh Ukrainy na period do 2020 roku (Zatverdzheno Nakazom Ministerstva oborony Ukrainy, 26.06.2017 r. № 342). 
8. Martsenkivskyi V., Kamalov Ye., Klontsak M. Otsiniuvannia efektyvnosti funktsionuvannia viiskovykh navchalnykh pidrozdiliv u systemi pidhotovky ofitseriv zapasu // Viiskova osvita. Zb. nauk. pr. Natsionalnoho universytetu oborony Ukrainy im. Ivana Cherniakhovskoho. 2020. №2(42). S.174-185.

9. Neshchadym M.I. Viiskova osvita v Ukraini: istoriia, teoriia, metodolohiia, praktyka: [monohrafiia]. K. : VPTs «Kyivsk. un-t», 2003. 852 s.

10. «Patriotyzm, mova ta zovnishnopolitychni priorytety» / Fond «Demokratychni initsiatyvy» im. I. Kucheriva; Tsentr Razumkova (hruden 2019 r.) [Elektronnyi resurs] https://dif.org.ua/article/\%20patriotyzm_mova\%20\%20

11. Polozhennia pro viiskovo-likarsku ekspertyzu v Zbroinykh Sylakh Ukrainy (Zatverdzheno Nakazom Ministra oborony Ukrainy, 14.08.2008 № 402).

12. Poltorakov Oleksii. Zakhystymo svii dim - zakhystymo Ukrainu // Ukrainskyi zhurnal. 2019. №12. S.21-23.

13. Poltorakov Oleksii. Chomu stari osvitnia y kadrova systemy blokuiut sotsialnu hotovnist i motyvatsiiu hromadian do sluzhby u viisku // Armiia Inform, 16.11.2020. [Elektronnyi resurs] https://armyinform.com.ua/2020/11/chomu-stari-osvitnya-j-kadrova-systemy-blokuyutsoczialnu-gotovnist-i-motyvacziyu-gromadyan-do-sluzhby-u-vijsku/

14. Poriadok provedennia viiskovoi pidhotovky hromadian Ukrainy za prohramoiu pidhotovky ofitseriv zapasu (Zatverdzheno Postanovoiu Kabinetu Ministriv Ukrainy, 01.02.2012 r. № 48)

15. Shchyhol Iryna. Takykh ne berut... v ofitsery zapasu: «druha molodist» chy «druhyi sort»? // Armiia Inform, 16.11.2020. [Elektronnyi resurs] https://armyinform.com.ua/2020/11/takyhne-berut-v-oficzery-zapasu-druga-molodist-chy-drugyj-sort/

\section{PЕЗЮМЕ}

Алексей Полтораков кандидат политических наук Военный институт Киевского национального университета им. Тараса Шевченка Ирина Щеголь факультет социологии Киевского национального университета им. Тараса Шевченка

\section{Социально-институциональные проблемы подготовки офицеров запаса в современной Украины}

Система подготовки младших офицеров (запаса) в украине, вполне соответствует векторам развития национального сектора безопасности и обороны (а прежде всего его кадрового сегмента). она требует принципиально серьезного реформирования, в т.ч. с учетом факторов социально-экономического и морально-психологического характера. предлагается оптимизировать распределение подготовки по военно-облийськовои специальности с учетом специфики региональных высших учебных заведений (технических, экономических и т.п.). акцентуализуеться проблема разработки, обеспечения и внедрения направлений и программ подготовки офицеров резерва для вновь системы тро.

Ключевые слова: высшее учебное заведение, военная кафедра, офицер запаса, регион, военно-облийськова специальность, эйджизм 


\section{SUMMARY}

Oleksii Poltorakov

candidate of political sciences

Military Institute of Kyiv National University

named after Taras Shevchenko

Iryna Shchyhol

Faculty of Sociology, Kyiv National University named after Taras Shevchenko

\section{Socio-institutional problems training of reserve officers in modern Ukraine}

The system of training junior officers (reserve) in ukraine does not sufficiently correspond to the vectors of development of the national security and defense sector (and above all its personnel segment). it requires fundamentally serious reforms, including taking into account factors of socio-economic and moral-psychological nature. it is proposed to optimize the distribution of training in the military-regional specialty, taking into account the specifics of regional higher education institutions (technical, economic). the problem of development, provision and implementation of directions and programs of training of reserve officers for the newly created tro system is accentuated.

Key words: higher educational institution, military department, reserve officer, region, military-obliyska specialty, ageism. 